\title{
Agronomic, physiological and quality response of romaine and red oak-leaf lettuce to nitrogen input
}

\author{
Francesco Di Gioia, ${ }^{1,2}$ Maria Gonnella, ${ }^{3}$ Vito Buono, ${ }^{1}$ Osman Ayala, ${ }^{3}$ Pietro Santamaria ${ }^{1}$ \\ ${ }^{1}$ Department of Agro-Environmental and Territorial Sciences, University of Bari, Italy; ${ }^{2}$ Institute of Food \\ and Agricultural Sciences, South West Florida Research and Education Center, University of Florida, \\ Immokalee, FL, USA; ${ }^{3}$ Institute of Sciences of Food Production, National Research Council, Bari, Italy
}

\begin{abstract}
Protecting the environment by improving the crop-system nitrogen $(\mathrm{N})$ use efficiency (NUE) while maximising yield and quality is a primary challenge for modern agriculture, and understanding the processes that govern $\mathrm{N}$ fluxes in the plant-soil system is essential to improve NUE. An on-farm study was conducted over two fall-winter seasons to evaluate the NUE, agronomical and physiological response of romaine (var. longifolia, cv Manavert) and red oak-leaf (var. crispa, cv Aruba) lettuce (Lactuca sativa L.) to different N-rates $\left(0,60,120,180 \mathrm{~kg} \mathrm{ha}^{-1}\right.$ of $\mathrm{N})$. Nitrogen rate influenced all tested parameters, including plant fresh and dry weight, $\mathrm{N}$ accumulation, leaf $\mathrm{NO}_{3}{ }^{-}$and dry matter content, NUE indices, $\mathrm{N}$ nutrition index (NNI), soil residual $\mathrm{N}$ and the estimated $\mathrm{N}$ losses at the end of the crop season. Fresh yield, dry weight and $\mathrm{N}$-accumulation response to $\mathrm{N}$ rate were influenced by lettuce genotype. Manavert had higher N recovery, NUE, and lower leaf $\mathrm{NO}_{3}{ }^{-}$concentration than Aruba. Analysing the NNI overtime, $120 \mathrm{~kg} \mathrm{ha}^{-1}$ of $\mathrm{N}$ assured an optimal $\mathrm{N}$ status in both Manavert and Aruba, while $\mathrm{N}$ deficiency and excess were observed at lower and higher N-rates, respectively. An empirical
\end{abstract}

Correspondence: Maria Gonnella, Institute of Sciences of Food Production, National Research Council, via Amendola, 122/O, 70126 Bari, Italy.

E-mail: maria.gonnella@ispa.cnr.it

Key words: EU Regulation No. 1258/2011; Lactuca sativa; Nitrate concentration; Nitrogen nutrition index; Nitrogen recovery.

Acknowledgments: this research was funded by the Inter-Regional research and innovation project AZORT. The authors wish to thank Nicola Gentile and Mina Florio for field and laboratory technical assistance.

Received for publication: 30 June 2016.

Revision received: 7 October 2016.

Accepted for publication: 15 October 2016.

(C) Copyright F. Di Gioia et al., 2017

Licensee PAGEPress, Italy

Italian Journal of Agronomy 2017; 12:806

doi:10.4081/ija.2017.806

This article is distributed under the terms of the Creative Commons Attribution Noncommercial License (by-nc 4.0) which permits any noncommercial use, distribution, and reproduction in any medium, provided the original author(s) and source are credited. relationship was observed between NNI and leaf $\mathrm{NO}_{3}{ }^{-}$concentration, suggesting that leaf $\mathrm{NO}_{3}{ }^{-}$concentration may be used to predict NNI and thus the crop N status. The relationship between NNI and leaf $\mathrm{NO}_{3}{ }^{-}$concentration may be used to define optimal leaf $\mathrm{NO}_{3}{ }^{-}$concentration ranges for the rapid and site-specific assessment of the crop $\mathrm{N}$ status, and the dynamic adjustment of $\mathrm{N}$-fertilisation, contributing to improve crop NUE, minimise N-losses, and optimise yield and quality of lettuce crops.

\section{Introduction}

Matching temporal and spatial nitrogen $(\mathrm{N})$ supply with $\mathrm{N}$ demand in vegetable crops, without incurring in excess or deficiency is still a challenging task for growers. Especially when dealing with crops like lettuce, characterised by shallow roots, high sensitivity to $\mathrm{N}$ deficiency (Broadley et al., 2000), relatively low $\mathrm{N}$ uptake efficiency (Greenwood et al., 1989), and high nitrate-accumulation capacity (Santamaria, 2006).

In spite of the relatively low $\mathrm{N}$ demand, during the early growth stage, lettuce crops require the maintenance of adequate levels of $\mathrm{N}$ in the root zone, because $\mathrm{N}$ shortage, even if temporary, can permanently compromise the final yield (Broadley et al., 2000). Nitrogen demand in lettuce crops is particularly high in the last third of the growing cycle, and sub-optimal $\mathrm{N}$ supply may lead to $\mathrm{N}$ deficiency with consequent yield reduction, poor quality and maturity delay (Salomez and Hofman, 2009). On the other hand, over applications of $\mathrm{N}$, exceeding crop $\mathrm{N}$ demand, may cause $\mathrm{N}$ luxury consumption with consequent nitrate accumulation (Di Gioia et al., 2013), and increase the risks of $\mathrm{N}$ losses, causing environmental pollution and contamination of water bodies and drinking water.

Vegetables are considered one of the major sources of human nitrate intake (Santamaria, 2006; Di Gioia et al., 2013). Despite there are increasing evidences that nitrate and nitrite may have a beneficial action against cardiovascular diseases (Hord et al., 2009), nitrates are considered anti-nutrients. Lettuce commercialisation is in fact subject to limits of the nitrate concentration set by the EC Regulation No. 194/97 (European Commission, 1997), recently amended and integrated by the EC Regulation No. 1258/2011 (European Commission, 2011), or to limits imposed by importing Countries and food-chain stores (Di Gioia et al., 2013).

Attempting to protect public health and environment, governments have implemented regulatory or volunteer measures and monitoring programmes aimed at reducing water pollution from agricultural sources. In Europe, with the Nitrates Directive (91/676/EEC), about $39.6 \%$ of the European Union (27 Member States) area has been designated as nitrate vulnerable zone (NVZ), and all Member States have defined good agricultural practices 
(GAPs) and have established action programmes in their NVZs (European Commission, 2010). Similarly, in the United States, with the definition of the Federal Total Maximum Daily Load mandate described in the Federal Clean Water Act (US Environmental Protection Agency, 2010), best management practices (BMPs) have been developed and implemented in each state, providing tools and important practices - including irrigation and fertilisation management practices aimed at reducing crop environmental impact while assuring optimal yields (Simonne et al., 2010).

The increased awareness of the potential impact of agricultural activities on the environment and on public health, and the mandatory or volunteer adoption of GAPs and/or BMPs is leading farmers to a more attentive approach to crop fertiliser management. Protecting the environment by improving crops nitrogen use efficiency (NUE) has become one of the primary and most challenging goals for farmers (Hirel et al., 2007).

Crop NUE, yield and quality are the result of a complex interaction between plant genotype, management practices and several environmental factors, and understanding the processes that govern $\mathrm{N}$ fluxes in the plant-soil system is of major importance in any attempt to improve NUE (Lemaire et al., 2008). A better knowledge of the factors that determine plant $\mathrm{N}$ uptake, accumulation and use efficiency during the crop cycle may enable the development of more rational fertiliser management strategies and technologies, thereby minimising the risks of $\mathrm{N}$ losses into the environment (Good et al., 2004).

The optimal $\mathrm{N}$ rate for a given crop is not constant, but can vary considerably from cultivar to cultivar, site to site, and season to season (Ozores-Hampton et al., 2015). Therefore, practical on farm management tools are required to rationalise crop $\mathrm{N}$ fertilisation. An approach to optimise crop $\mathrm{N}$ fertiliser management consists in implementing modern site-specific management strategies, which may involve the use of diagnostic tools for the assessment of the crop or soil $\mathrm{N}$ status during the growing season (Peña-Fleitas et al., 2015), or the use of models and decision support systems (Conversa et al., 2015). Nevertheless, the implementation of sitespecific $\mathrm{N}$ management strategies requires knowledge and basic information on $\mathrm{N}$ crop demand and accumulation, soil $\mathrm{N}$ mineralisation, potential $\mathrm{N}$ losses and residue, and crop NUE. Such basic information may be used to develop, calibrate and update predictive models, and to develop monitoring techniques and indicators of the soil-crop system $\mathrm{N}$ status, capable of detecting or predicting both $\mathrm{N}$ deficiency and excesses. Moreover, established indicators of the crop nutrient status, such as the N nutrition index (NNI) proposed by Lemaire et al. (1989) may be used to define optimal $\mathrm{N}$ rates, and test monitoring techniques and the reliability of diagnostic tools and indicators of the plant and soil $\mathrm{N}$ status.

Given the importance of lettuce crops, grown at global level on over a million of hectares every year (FAOSTAT, 2016), a field study was conducted to analyse and compare the agronomic, physiological and quality response of romaine (heading) and red oakleaf (non-heading) lettuce to $\mathrm{N}$ inputs. Specific objectives of the study were: i) evaluate $\mathrm{N}$ rate effects on yield, $\mathrm{N}$, nitrate and dry matter accumulation of both genotypes; ii) estimate their $\mathrm{N}$ recovery and utilisation efficiency, and potential soil $\mathrm{N}$ losses; iii) analyse a posteriori the crop $\mathrm{N}$ status and the optimal $\mathrm{N}$ rate for both genotypes using the NNI; and iv) evaluate the possibility to predict the NNI, and thus, the crop $\mathrm{N}$ status through the leaf $\mathrm{NO}_{3}{ }^{-}$concentration.

\section{Materials and methods}

\section{Plant material, growing conditions and experimental design}

Two field experiments were conducted on-farm at Conversano $\left(40^{\circ} 58^{\prime} \mathrm{N}, 17^{\circ} 7^{\prime} \mathrm{E} ; 140 \mathrm{~m}\right.$ asl) and Polignano a Mare (40 $59^{\prime} \mathrm{N}$, $17^{\circ} 13^{\prime} \mathrm{E}$; $40 \mathrm{~m}$ asl), in Southern Italy, during the fall-winter season of 2006-2007 (Exp-1) and 2007-2008 (Exp-2), respectively. In both sites the soil was a typical Mediterranean Terra Rossa (red earth) clay soil, classified as Alfisols according to the U.S. Department of Agriculture soil taxonomy (USDA, 2003), or as Luvisols according to the World Reference Base for soil resources (WRB, 2006). Soil chemical properties were as follows (for Exp-1 and Exp-2, respectively): organic matter 14.4 and $14.7 \mathrm{~g} \mathrm{~kg}^{-1}$, total $\mathrm{N} 1.02$ and $1.35 \mathrm{~g} \mathrm{~kg}^{-1}$, organic carbon 8.4 and $8.5 \mathrm{~g} \mathrm{~kg}^{-1}, \mathrm{C} / \mathrm{N} 8.13$ and $6.3, \mathrm{P}_{2} \mathrm{O}_{5} 364.7$ and $688.3 \mathrm{mg} \mathrm{kg}^{-1}, \mathrm{~K}_{2} \mathrm{O} 130.6$ and $196.9 \mathrm{mg}$ $\mathrm{kg}^{-1}$, cation exchange capacity 291.9 and 258.8 meq kg-1, $\mathrm{pH} 7.8$ and 7.0 , electrical conductivity 0.5 and $1.1 \mathrm{dS} \mathrm{m}^{-1}$.

On 3 November of 2006 and 30 October of 2007, romaine (var. longifolia, cv Manavert; Enza Zaden Italia s.r.l., Tarquinia, Italy) and red oak-leaf (var. crispa, cv Aruba; Enza Zaden Italia s.r.1.) lettuce (Lactuca sativa L.) were transplanted at the third true-leaf stage in rows $0.35 \mathrm{~m}$ apart, establishing a density of 9.5 plants $\mathrm{m}^{-2}$. Both cultivars were harvested at 105 and 94 days after transplanting (DAT), in Exp-1 and Exp-2, respectively.

In both experiments, four $\mathrm{N}$ rates $\left[0\left(\mathrm{~N}_{0}\right), 60\left(\mathrm{~N}_{60}\right), 120\left(\mathrm{~N}_{120}\right)\right.$, and $180\left(\mathrm{~N}_{180}\right) \mathrm{kg} \mathrm{ha}^{-1}$ of $\left.\mathrm{N}\right]$ were applied through side-dressing, $50 \%$ as ammonium sulphate in pre-transplanting and $50 \%$ as ammonium nitrate in post transplanting at 48 and 40 DAT in Exp1 and Exp-2, respectively. An unfertilised control was included to calculate the crop NUE, and estimate $\mathrm{N}$ soil mineralisation. Treatments were arranged according to a split plot experimental design with three replicates in both experiments. The cultivars (Manavert and Aruba) were arranged in the main plots, while $\mathrm{N}$ rates were randomised in subplots of $21 \mathrm{~m}^{2}(3.5 \mathrm{~m}$ wide and $6 \mathrm{~m}$ long). Crop water requirements were satisfied by rainfall events (about $64.6 \mathrm{~mm}$ in Exp-1 and $144 \mathrm{~mm}$ in Exp-2) and supplemental irrigation (about $85 \mathrm{~mm}$ and $50 \mathrm{~mm}$, respectively) applied using low-pressure mini-sprinkler irrigators, which represents the most common irrigation method used in the area for leafy vegetables. An integrated crop protection management approach was used to control weeds, pests, and main diseases. Meteorological data for both seasons were recorded and provided by the local public service, considering the closest weather station of the existing network. Mean daily air temperature was on average 10.3 and $9.1^{\circ} \mathrm{C}$ in Exp-1 and Exp-2, respectively. In Exp-1, daily minimum and maximum air temperature ranged from 0 to $9.1^{\circ} \mathrm{C}$ and from 12.3 to $22.4^{\circ} \mathrm{C}$, respectively (Figure 1). In Exp-2, daily minimum and maximum air temperature ranged from -4.7 to $2.4^{\circ} \mathrm{C}$ and from 15.8 to $23.4^{\circ} \mathrm{C}$, respectively. Temperatures below $0^{\circ} \mathrm{C}$ reduced plant growth but did not damage both lettuce genotypes. During the growing season, cumulative solar radiation was 978 and $503 \mathrm{MJ}$ $\mathrm{m}^{-2}$ in Exp-1 and Exp-2, respectively.

\section{Plant growth analysis, tissue and soil laboratory analysis}

Total aboveground fresh weight (FW) was measured on a sample of six plants per plot, at 20, 47, 61, 75 and 105 DAT in Exp-1, and 28, 49, 66 and 94 DAT in Exp-2. Plant samples were ovendried at $65^{\circ} \mathrm{C}$ until constant weight to determine dry weight (DW) and dry matter (DM) content. Oven-dried plant samples were finely ground through a mill (IKA; Labortechnik, Staufen, Germany) 
and used for quantitative chemical analyses. Total $\mathrm{N}$ was determined by Kjeldahl method ( 2300 Kjeltec Auto Analyser) with the addition of salicylic acid for the recovery of the $\mathrm{NO}_{3}-\mathrm{N}$ (Simonne et al., 1997). Nitrates, previously extracted from dry matter samples of $0.5 \mathrm{~g}$ with $50 \mathrm{~mL}$ of sodium carbonate $(3.5 \mathrm{mM})$ and sodium bicarbonate $(1.0 \mathrm{mM})$ solution, were determined by ion chromatography (model Dionex DX500; Dionex Corp., Sunnyvale, CA, USA) as described by Boari et al. (2013).

Only for the cv Manavert, soil samples were collected before $\mathrm{N}$ treatment $\left(\mathrm{N}_{0}, \mathrm{~N}_{60}, \mathrm{~N}_{120}\right.$ and $\left.\mathrm{N}_{180}\right)$ application and at harvest, 105 and 94 DAT for Exp-1 and Exp-2, respectively, to monitor the soil mineral $\mathrm{N}\left(\mathrm{NO}_{3}{ }^{-}\right.$and $\left.\mathrm{NH}_{4}{ }^{+}\right)$content. Using an Eijkelkamp soil auger with a diameter of $5 \mathrm{~cm}$, four borings per plot were taken at $30 \mathrm{~cm}$ depth, excluding border rows. Subsamples were combined in a single bulk sample per plot. Soil samples were stored in freezer $\left(-18^{\circ} \mathrm{C}\right)$ pending analysis, then were defrosted at $4^{\circ} \mathrm{C}$ and extraction was conducted on two subsamples within 24 hours with a 1:4 ratio (w/w) soil: $0.025 \mathrm{M} \mathrm{KCl}$ solution. The filtered solution was then analysed to determine $\mathrm{NO}_{3}-\mathrm{N}$ and $\mathrm{NH}_{4}-\mathrm{N}$ content by ion chromatography (model QIC; Dionex Corp.). Values of $\mathrm{NH}_{4}-\mathrm{N}$ were negligible or below detection limit during both seasons (data not shown).

Soil core subsamples collected in pre-transplanting were airdried, sieved to $2 \mathrm{~mm}$, and used for soil physical and chemical characterisation.

\section{Nitrogen use efficiency indices and nitrogen nutrition index calculation}

Total $\mathrm{N}$ accumulation $\left(\mathrm{N}_{\mathrm{acc}} ; \mathrm{kg} \cdot \mathrm{ha}^{-1}\right)$ was calculated multiplying the aboveground DW by the total $\mathrm{N}$ concentration. In correspondence of each sampling date, the critical nitrogen $\left(\mathrm{N}_{\text {crit }}\right)$ content, which is defined as the minimum $\mathrm{N}$ concentration in the aboveground biomass required for maximum growth, was calculated as proposed by Justes et al. (1994) according to the equation parametrised by Tei et al. (2003) for lettuce:

$\mathrm{N}_{\text {crit }}=4.56 \times \mathrm{DW}^{-0.357}$

The NNI was calculated as proposed by Lemaire et al. (1989), dividing the measured $\mathrm{N}$ concentration of the aboveground biomass $\left(\% \mathrm{~N}_{\mathrm{DW}}\right)$ by the predicted $\% \mathrm{~N}_{\text {crit }}$ :

$\mathrm{NNI}=\% \mathrm{~N}_{\mathrm{DW}} / \mathrm{N}_{\text {crit }}$

At final harvest NUE indices were calculated for each $\mathrm{N}$ rate according to Elia and Conversa (2012) as follows.

First, apparent $\mathrm{N}$ fertiliser recovery efficiency $\left(\mathrm{REC}_{\mathrm{N}}\right)$ by the crop, which represents the $\mathrm{kg}$ increase in $\mathrm{N}_{\text {acc }}$ per $\mathrm{kg}$ of applied $\mathrm{N}$ :

$\mathrm{REC}_{\mathrm{N}}=\left(\mathrm{A}_{\mathrm{F}}-\mathrm{A}_{0}\right) / \mathrm{N}_{\mathrm{F}}$

Second, partial factor productivity of applied N $\left(\mathrm{PFP}_{\mathrm{N}}\right)$, which represents the $\mathrm{kg}$ of product harvested per $\mathrm{kg}$ of applied $\mathrm{N}$ :

$\mathrm{PFP}_{\mathrm{N}}=\mathrm{Y}_{\mathrm{F}} / \mathrm{N}_{\mathrm{F}}$

Third, agronomic efficiency of applied $\mathrm{N}\left(\mathrm{AE}_{\mathrm{N}}\right)$, which represents the $\mathrm{kg}$ of yield increase per $\mathrm{kg}$ of applied $\mathrm{N}$ :

$\mathrm{AE}_{\mathrm{N}}=\left(\mathrm{Y}_{\mathrm{F}}-\mathrm{Y}_{0}\right) / \mathrm{N}_{\mathrm{F}}$

Fourth, physiological efficiency of applied $\mathrm{N}\left(\mathrm{PE}_{\mathrm{N}}\right)$, which repre- sents the $\mathrm{kg}$ of yield increase per kg increase in $\mathrm{N}_{\mathrm{acc}}$ from fertiliser:

$\mathrm{PE}_{\mathrm{N}}=\mathrm{Y}_{\mathrm{F}}-\mathrm{N}_{0} / \mathrm{A}_{\mathrm{F}}-\mathrm{A}_{0}$

where: $Y_{F}$ is the crop yield $\left(\mathrm{kg} \mathrm{ha}^{-1}\right)$ obtained with the application of a determinate $\mathrm{N}$-fertiliser $\left(\mathrm{N}_{\mathrm{F}}\right)$ rate $\left(\mathrm{kg} \mathrm{ha}^{-1}\right) ; \mathrm{Y}_{0}$ is the crop yield obtained in the unfertilised control; $\mathrm{A}_{\mathrm{F}}$ is the total plant $\mathrm{N}_{\text {acc }}\left(\mathrm{kg} \mathrm{ha}^{-1}\right)$ in aboveground biomass at maturity when an amount of $\mathrm{N}_{\mathrm{F}}$ is applied, and $\mathrm{A}_{0}$ is the corresponding total plant $\mathrm{N}_{\mathrm{acc}}\left(\mathrm{kg} \mathrm{ha}^{-1}\right)$ in aboveground biomass at maturity when no N-fertiliser is applied. Nitrogen use efficiency indices were calculated both on fresh and dry weight basis.

\section{Soil nitrogen mineralisation and losses estimate}

Nitrogen derived from the mineralisation of the soil organic matter $\left(\mathrm{N}_{\text {organic }}\right)$ in each growing season was estimated by subtracting the initial soil inorganic $\mathrm{N}\left(\mathrm{N}_{\min }\right)$ content of the top $30-\mathrm{cm}$ soil layer in unfertilised control $\left(0 \mathrm{~kg} \mathrm{ha}^{-1}\right.$ of $\left.\mathrm{N}\right)$ from the sum of aboveground $\mathrm{N}_{\text {acc }}$ and residual soil $\mathrm{N}_{\min }$ at harvest in the same soil layer according to Cui et al. (2010):

$\mathrm{N}_{\text {organic }}=\left(\right.$ soilN $\left.\mathrm{N}_{\min (\text { residual) }}+\mathrm{cropN}_{\mathrm{acc}}\right)-\operatorname{soilN}_{\min \text { (initial) }}$

Nitrogen losses were estimated as difference between $\mathrm{N}$ inputs (initial soil $\mathrm{N}_{\min }$, apparent $\mathrm{N}$ mineralisation, applied $\mathrm{N}_{\mathrm{F}}$ ), and outputs (aboveground $\mathrm{N}_{\text {acc }}$, residual soil $\mathrm{N}_{\min }$ ):
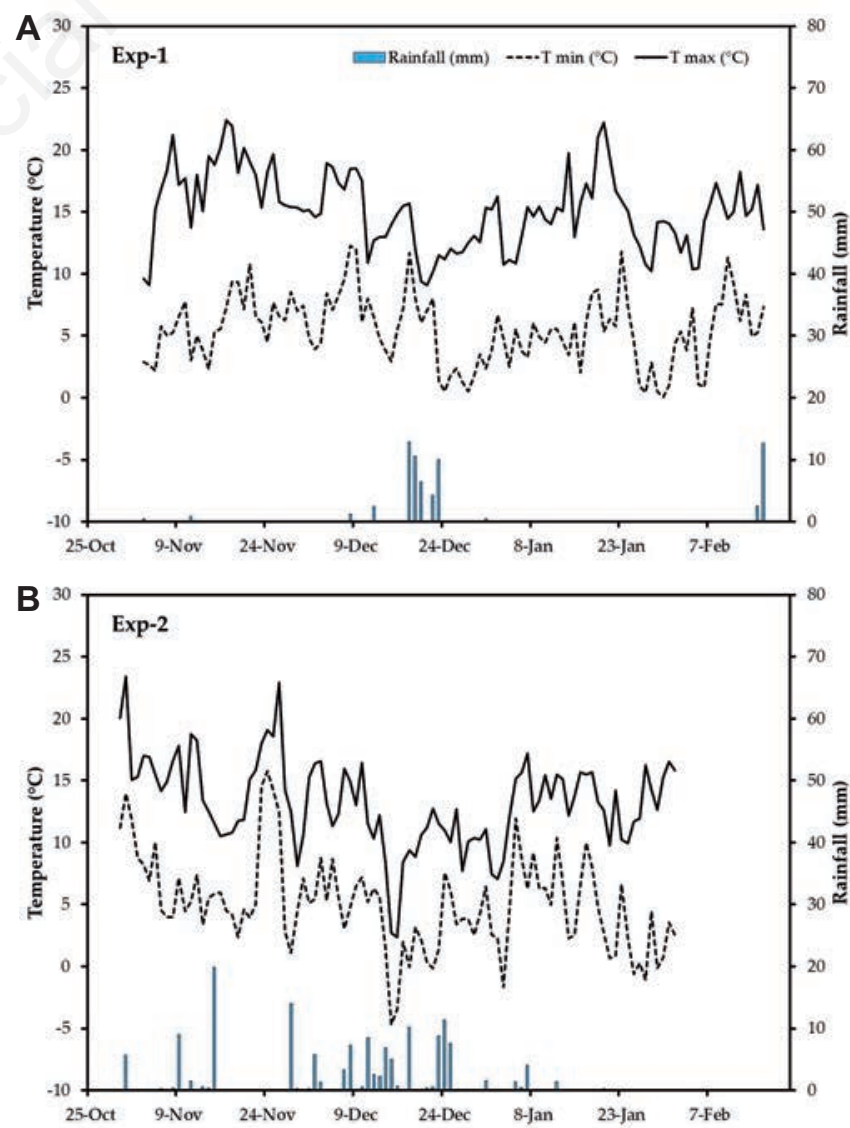

Figure 1. Daily minimum and maximum temperature and rainfall recorded at Conversano and Polignano a Mare (Southern Italy), during the fall-winter season of 2006-2007 (Exp-1; A) and 20072008 (Exp-2; B), respectively. 
Nlosses $=\left(\right.$ soil $\left._{\text {min (initial) }}+\mathrm{N}_{\text {organic }}+\mathrm{N}_{\mathrm{F}}\right)-$

$\left(\right.$ soilN $_{\min \text { (residual) }}+$ cropN $_{\text {acc }}$ )

(Eq. 8)

where: soil $\mathrm{N}_{\min (\text { initial) }}$ and (residual) were the inorganic $\mathrm{N}$ content of the top 30-cm soil layer, before pre-planting fertiliser application and at harvest, respectively.

\section{Statistical analysis}

Statistical analysis was performed separately for each experiment. Analysis of variance (ANOVA) was performed using the GLM procedure of SAS software package (SAS Institute Inc., Cary, NC, USA). Linear and quadratic regression analyses were performed using PROC REG of SAS to estimate the parameters of the relationships between $\mathrm{N}$ rate and $\mathrm{FW}, \mathrm{DW}$, and $\mathrm{N}_{\mathrm{acc}}$ at harvest. All means were compared by the least significant difference (LSD) test, at $5 \%$ level of probability.

\section{Results}

\section{Effect of nitrogen supply on fresh yield, dry biomass and nitrogen accumulation}

Nitrogen rate and lettuce genotype influenced plant FW, DW and $\mathrm{N}_{\text {acc }}$ (Figure 2). In both experiments, at harvest (105 and 94 DAT in Exp-1 and Exp-2, respectively) FW, DW and $\mathrm{N}_{\text {acc }}$ were on average 2.2, 1.8 and 1.5 times higher in Manavert than in Aruba (Figure 2), respectively.

Except for the $\mathrm{N}_{\text {acc }}$ response to $\mathrm{N}$ rate of the cv Manavert in Exp-2 (Figure 2C), a second order polynomial function showed always a better fit than the linear function, as demonstrated by the higher adjusted $\mathrm{R}^{2}\left(\mathrm{Adj}^{2}\right.$ ) coefficient (Table 1). Nevertheless, the quadratic coefficients were very low, especially in the case of the relationship between $\mathrm{N}$ rate and DW (Table 1).

Based on the estimated quadratic functions the optimal $\mathrm{N}$ rates to achieve the maximum fresh yield were 182 and $148 \mathrm{~kg} \mathrm{ha}^{-1}$ for Manavert, and 160 and $169 \mathrm{~kg} \mathrm{ha}^{-1}$ of $\mathrm{N}$ for Aruba, in Exp-1 and Exp-2, respectively (Figure 2A). Considering the DW, estimated optimal $\mathrm{N}$ rates ranged between 145 and $160 \mathrm{~kg} \mathrm{ha}^{-1}$ of $\mathrm{N}$ for both cultivars and experiments (Figure 2B).

\section{Effect of nitrogen supply on nitrate and dry matter plant content}

Leaf $\mathrm{NO}_{3}{ }^{-}$concentration was higher in Aruba than in Manavert in both experiments (Figure 3A and B). In both experiments, Aruba increased the leaf $\mathrm{NO}_{3}{ }^{-}$concentration with increasing $\mathrm{N}$ rate, whereas Manavert increased the leaf $\mathrm{NO}_{3}{ }^{-}$concentration only when grown with $\mathrm{N}_{120}$ and $\mathrm{N}_{180}$. Maximum leaf $\mathrm{NO}_{3}{ }^{-}$concentration values achieved with $\mathrm{N}_{180}$ were on average 1534 and $1881 \mathrm{mg} \mathrm{kg}^{-1}$ of FW for Aruba, and 1042 and $685 \mathrm{mg} \mathrm{kg}^{-1}$ of FW for Manavert, in Exp-1 and Exp-2, respectively (Figure 3A and B). In Exp-1, the DM percentage was not different between the two cultivars at $\mathrm{N}_{60}$. When non-fertilised $\left(\mathrm{N}_{0}\right)$ Manavert had a higher DM content compared to Aruba, while when fertilised with the highest $\mathrm{N}$ rates $\left(\mathrm{N}_{120}\right.$ and $\mathrm{N}_{180}$ ) Manavert DM content was lower than in Aruba. Instead, in Exp-2 the DM content was consistently higher $(\mathrm{P}=0.01)$ in Aruba than in Manavert regardless the $\mathrm{N}$ rate (Figures $3 \mathrm{C}$ and $\mathrm{D}$ ). The DM content was higher in unfertilised plants than in fertilised ones, in both experiments, except for Aruba grown with $\mathrm{N}_{60}$ that in Exp-2 had DM values similar to the unfertilised plants. In Exp-1 only for Manavert, DM content was higher with $\mathrm{N}_{60}$ than in plants grown at higher $\mathrm{N}$ rate (Figure $3 \mathrm{C}$ ).
An inverse relationship was observed between DM and leaf $\mathrm{NO}_{3}{ }^{-}$concentration: with increasing the $\mathrm{N}$ fertiliser rate the leaf $\mathrm{NO}_{3}{ }^{-}$concentration increased, while the DM content decreased in both cultivars and experiments (Figure 4).

\section{Nitrogen use efficiency and its components}

In Exp-1, $\mathrm{REC}_{\mathrm{N}}$ was lower $(\mathrm{P}=0.02)$ in Aruba than in Manavert ( $32 \%$ vs $42 \%$, respectively), while in Exp-2 it was on average $22 \%$ and was not different between cultivars (Figure 5). In both experiments the $\mathrm{REC}_{\mathrm{N}}$ was not significantly influenced by $\mathrm{N}$ rate in Manavert, while it decreased with the highest $\mathrm{N}$ rate in Aruba
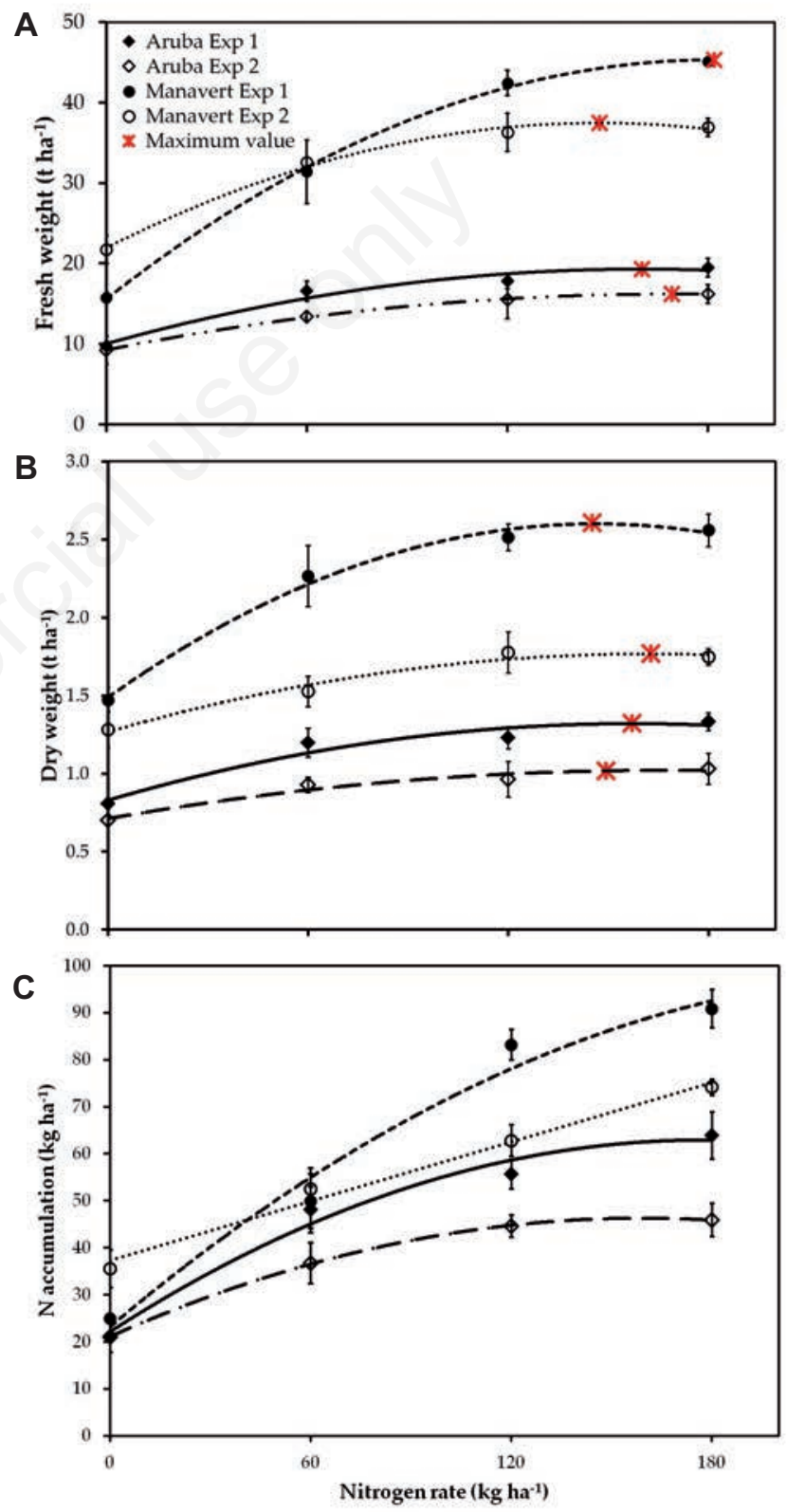

Figure 2. Final aboveground fresh weight (A), dry weight (B), and $\mathrm{N}$ accumulation $(\mathrm{C})$ as functions of nitrogen fertiliser rates in romaine (cv Manavert) and red oak-leaf (cv Aruba) lettuce grown at Conversano and Polignano a Mare (Southern Italy), during the fall-winter season of 2006-2007 (Exp-1) and 2007-2008 (Exp-2), respectively. Vertical bars represent \pm standard error $(n=3)$. 
(Figure 5). The $\mathrm{PFP}_{\mathrm{N}}$ decreased $(\mathrm{P}<0.001)$ as the $\mathrm{N}$ rate increased in both cultivars and experiments (Figure 6A). In both experiments the $\mathrm{PFP}_{\mathrm{N}}$ was higher $(\mathrm{P}<0.001)$ in Manavert than in Aruba, however, $\mathrm{PFP}_{\mathrm{N}}$ values were lower in Exp-2 than in Exp-1. The $\mathrm{AE}_{\mathrm{N}}$ was lower $(\mathrm{P}<0.001)$ in Aruba (on average $4.2 \mathrm{~kg}$ of $\mathrm{DW} \mathrm{kg}-1$ of $\mathrm{N}$ ) than in Manavert (on average $9.3 \mathrm{~kg}$ of DW kg-1 of $\mathrm{N}$ ) in Exp-1, whereas no differences were found in Exp-2, $\mathrm{AE}_{\mathrm{N}}$ was on average
2.8 and $3.6 \mathrm{~kg}$ of DW kg-1 of $\mathrm{N}$ in Aruba and Manavert, respectively (Figure 6C). The $\mathrm{PE}_{\mathrm{N}}$ ranged on average between 13 and 14 $\mathrm{kg}$ of DW per $\mathrm{kg}$ of increased $\mathrm{N}_{\mathrm{acc}}$, in both cultivars and experiments regardless the level of $\mathrm{N}$ supply, except for the cv Manavert that in Exp-1 had higher $(\mathrm{P}<0.001) \mathrm{PE}_{\mathrm{N}}$ values with $\mathrm{N}_{60}(32.5 \mathrm{~kg}$ of DW kg-1 N) than with $\mathrm{N}_{120}\left(17.8 \mathrm{~kg}^{-1} \mathrm{DW} \mathrm{kg}-1 \mathrm{~N}\right)$ and $\mathrm{N}_{180}$ $\left(16.4 \mathrm{~kg}\right.$ of $\left.\mathrm{DW} \mathrm{kg} \mathrm{kg}^{-1} \mathrm{~N}\right)$.
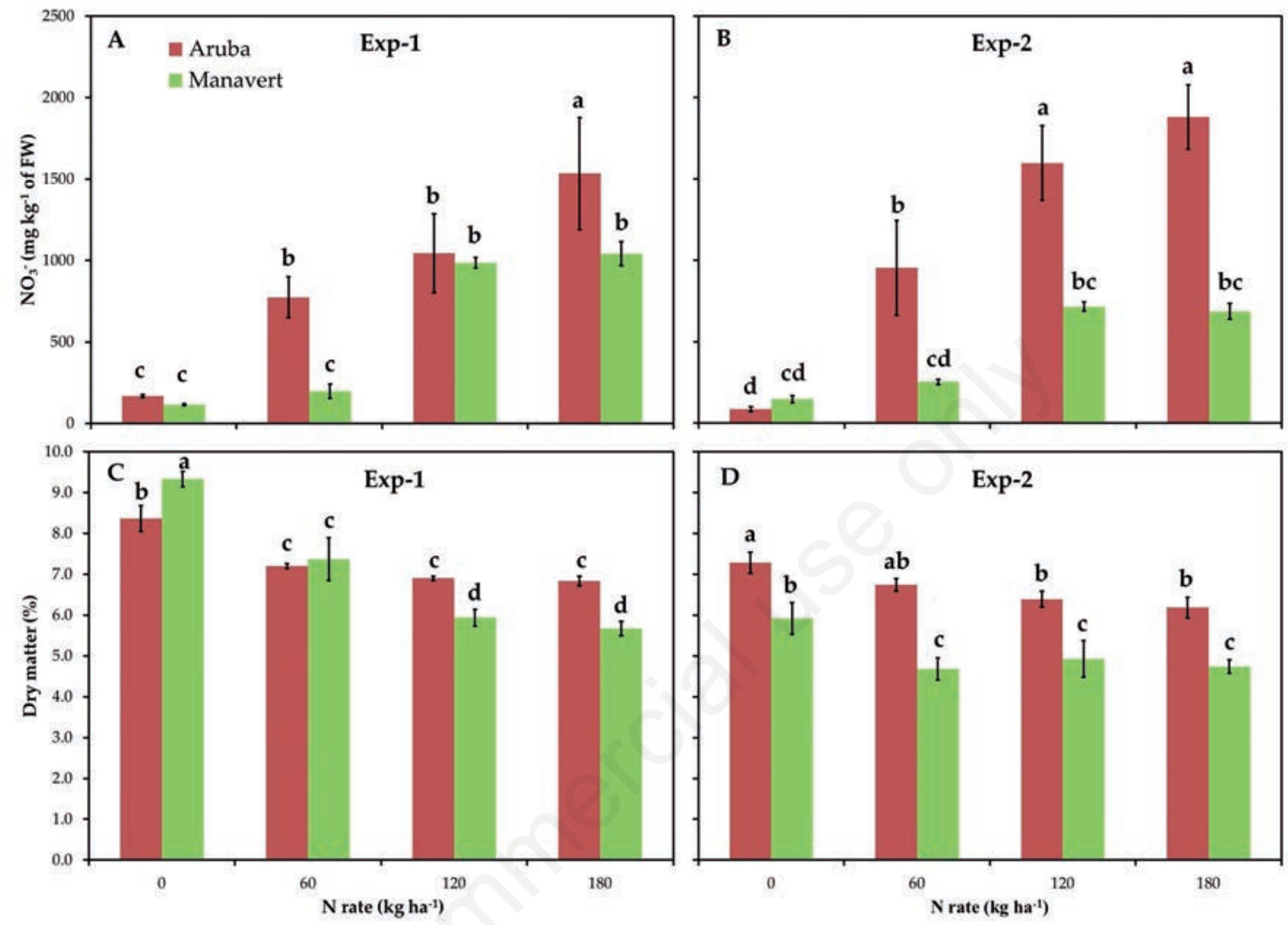

Figure 3. Effect of nitrogen fertiliser rate on nitrate accumulation (A and B) and dry matter content $(C$ and $D)$ observed at final harvest in cv Aruba (red oak-leaf) and cv Manavert (romaine), grown at Conversano and Polignano a Mare, during the fall-winter season of 2006-2007 (Exp-1) and 2007-2008 (Exp-2), respectively. Vertical bars represent \pm standard error $(\mathrm{n}=3)$. Different letters indicate significant differences at $\mathbf{P}=0.05$.

Table 1. Parameter estimates, their significance, and adjusted $\mathbf{R}^{2}$ for the function representing the fresh weight-, dry weight- and nitrogen uptake-nitrogen rate relationships in lettuce cv Aruba and Manavert grown with different levels of nitrogen supply in two Mediterranean locations in 2006-2007 and 2007-2008 fall-winter cropping seasons.

\begin{tabular}{|c|c|c|c|c|c|c|c|c|c|c|}
\hline \multirow[t]{2}{*}{ Experiment } & & \multirow[t]{2}{*}{ Cultivar } & \multicolumn{2}{|c|}{ Intercept $^{\circ}$} & \multicolumn{2}{|c|}{ Slope $^{\circ}$} & \multicolumn{2}{|c|}{$\begin{array}{l}\text { Quadratic } \\
\text { coefficient }^{\circ}\end{array}$} & \multirow{2}{*}{$\begin{array}{c}\text { Adjusted } \mathrm{R}^{2} \\
\text { quadratic } \\
\text { function }\end{array}$} & \multirow{2}{*}{$\begin{array}{l}\text { Adjusted } \mathrm{R}^{2} \\
\text { linear } \\
\text { function }\end{array}$} \\
\hline & & & Estimate & $\mathbf{P}$ & Estimate & $\mathbf{P}$ & Estimate & $\mathbf{P}$ & & \\
\hline \multirow[t]{4}{*}{ FW-N rate relationship } & Exp-1 & Aruba & 10.02 & 0.01 & 0.12 & 0.01 & -0.00036 & 0.03 & 0.81 & 0.71 \\
\hline & & Manavert & 15.56 & 0.01 & 0.33 & 0.01 & -0.00090 & 0.01 & 0.92 & 0.85 \\
\hline & Exp-2 & Aruba & 9.25 & 0.01 & 0.08 & 0.01 & -0.00024 & 0.12 & 0.71 & 0.65 \\
\hline & & Manavert & 21.93 & 0.01 & 0.21 & 0.01 & -0.00071 & 0.01 & 0.85 & 0.69 \\
\hline \multirow[t]{4}{*}{ DW-N rate relationship } & Exp-1 & Aruba & 0.83 & 0.01 & 0.006 & 0.01 & -0.000020 & 0.07 & 0.72 & 0.63 \\
\hline & & Manavert & 1.49 & 0.01 & 0.015 & 0.01 & -0.000053 & 0.01 & 0.83 & 0.66 \\
\hline & Exp-2 & Aruba & 0.67 & 0.01 & 0.005 & 0.04 & -0.000015 & 0.17 & 0.51 & 0.44 \\
\hline & & Manavert & 1.27 & 0.01 & 0.006 & 0.04 & -0.000019 & 0.21 & 0.55 & 0.51 \\
\hline \multirow{4}{*}{$\begin{array}{l}\mathrm{N} \text { uptake-N rate } \\
\text { relationship }\end{array}$} & Exp-1 & Aruba & 22.15 & 0.01 & 0.46 & 0.01 & -0.00130 & 0.04 & 0.85 & 0.78 \\
\hline & & Manavert & 23.20 & 0.01 & 0.60 & 0.01 & -0.00121 & 0.08 & 0.92 & 0.90 \\
\hline & Exp-2 & Aruba & 21.13 & 0.01 & 0.32 & 0.01 & -0.00100 & 0.05 & 0.76 & 0.67 \\
\hline & & Manavert & 35.92 & 0.01 & 0.28 & 0.01 & -0.00038 & 0.44 & 0.85 & 0.86 \\
\hline
\end{tabular}

FW, fresh weight; N, nitrogen; DW, dry weight; Exp-1, field experiment 1 conducted on-farm at Conversano (40 $58^{\prime} \mathrm{N}, 17^{\circ} 77^{\prime} \mathrm{E}$; $140 \mathrm{~m}$ asl) during the fall-winter season of $2006-2007$; Exp-2, field experiment 2 conducted on-farm at Polignano a Mare $\left(40^{\circ} 59^{\prime} \mathrm{N}, 17^{\circ} 13^{\prime} \mathrm{E} ; 40 \mathrm{~m}\right.$ asl) during the fall-winter season of 2007-2008. ${ }^{\circ}$ Intercepts, slopes and quadratic coefficients in italics are not significantly different from zero at the $5 \%$ level. 
Calculated on $\mathrm{FW}$ basis $\mathrm{PFP}_{\mathrm{N}}, \mathrm{AE}_{\mathrm{N}}$ and $\mathrm{PE}_{\mathrm{N}}$ assumed a different trend as compared to the same indices calculated on DW basis: $\mathrm{PFP}_{\mathrm{N}}, \mathrm{AE}_{\mathrm{N}}$ and $\mathrm{PE}_{\mathrm{N}}$ values were consistently higher in Manavert than in Aruba in both experiments (Figure 6B, D, F).

\section{Soil nitrate residual and nitrogen losses estimate}

In Exp-1, at harvest, residual soil $\mathrm{NO}_{3}-\mathrm{N}$ content in the top 30$\mathrm{cm}$ of soil in plots of Manavert was not influenced by $\mathrm{N}$ rates and was on average $26.8 \mathrm{~kg} \mathrm{ha}^{-1}$ (Figure 7A). In Exp-2, residual soil $\mathrm{NO}_{3}-\mathrm{N}$ content was on average $15.0 \mathrm{~kg} \mathrm{ha}^{-1}$, ranging from $6.6 \mathrm{~kg}$ $\mathrm{ha}^{-1}$ in treatment $\mathrm{N}_{60}$ to $29.0 \mathrm{~kg} \mathrm{ha}^{-1}$ in treatment $\mathrm{N}_{180}$. Residual soil $\mathrm{NO}_{3}-\mathrm{N}$ was higher $(\mathrm{P}=0.003)$ with $\mathrm{N}_{180}$ than with lower $\mathrm{N}$ rates (Figure 7A). In both experiments, estimated $\mathrm{N}$ losses from the top $30-\mathrm{cm}$ of soil in plots of Manavert increased $(\mathrm{P}<0.001)$ with increasing the $\mathrm{N}$ rate (Figure $7 \mathrm{~B}$ ). Estimated $\mathrm{N}$ losses for treatments $\mathrm{N}_{60}, \mathrm{~N}_{120}$ and $\mathrm{N}_{180}$ were 32, 55 and $111 \mathrm{~kg} \mathrm{ha}^{-1}$ in Exp-1, and 44, 83 and $125 \mathrm{~kg} \mathrm{ha}^{-1}$ in Exp-2, respectively (Figure 7B).

\section{Nitrogen nutrition index and relationship with nitrate content}

Analysing the NNI time course during the crop cycle, for each level of $\mathrm{N}$ supply, it was observed that in both genotypes and experiments, the $\mathrm{N}$ status of plant grown at different $\mathrm{N}$ rates started to diverge at 60 DAT. After 60 DAT, the NNI was always lower than 1.0 (optimal $\mathrm{N}$ status) in unfertilised plants or in those grown at lower $\mathrm{N}$ rate $\left(\mathrm{N}_{60}\right)$, proving the occurrence of $\mathrm{N}$ deficiency. In plants grown at higher $\mathrm{N}$ rates $\left(\mathrm{N}_{120}\right.$ and $\left.\mathrm{N}_{180}\right)$ the NNI remained close to 1.0 during the entire crop cycle, and only at harvest, plants fertilised with $\mathrm{N}_{180}$ had NNI values above 1.0, revealing the occurrence of N luxury consumption (Figure 8). Based on the NNI timecourse, in both cultivars and experiments, only the application of $120 \mathrm{~kg} \mathrm{ha}^{-1}$ of $\mathrm{N}$ assured the maintenance of an optimal crop $\mathrm{N}$ status during the entire crop cycle, while $\mathrm{N}$ deficiency or luxury consumption were observed at lower and higher $\mathrm{N}$ rates, respectively.

Analysing the variation of the leaf $\mathrm{NO}_{3}-\mathrm{N}\left(\mathrm{g} 100 \mathrm{~g}^{-1}\right.$ of DW) to total-N (g $100 \mathrm{~g}^{-1}$ of DW) ratio in relation to the NNI, in both cultivars and experiments, it was observed that the fraction of $\mathrm{NO}_{3}$ -

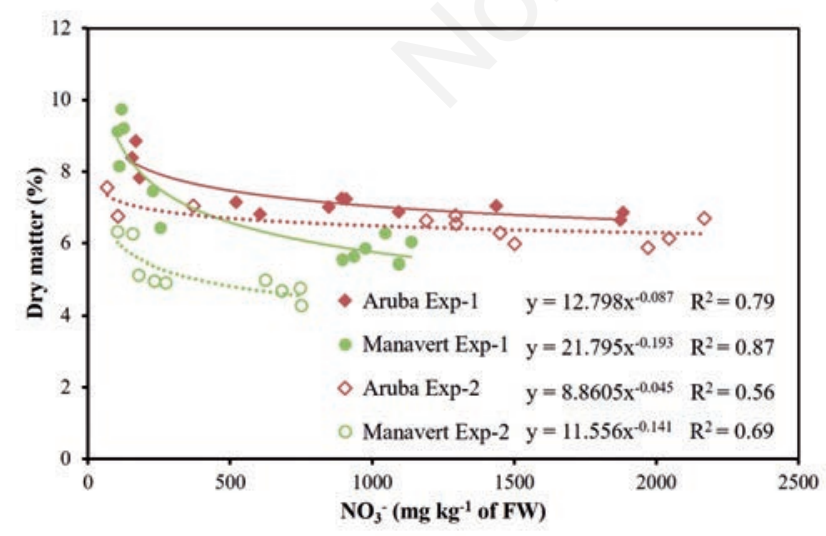

Figure 4. Variation of the dry matter content (\%) in function of nitrate concentration in cv Manavert (romaine) and cv Aruba (red oak-leaf), grown at Conversano and Polignano a Mare, during the fall-winter season of 2006-2007 (Exp-1) and 2007-2008 (Exp-2), respectively. Regression lines are negative power functions representing the specific relationships between the two variables in both cultivars and experiments $(n=3)$.
$\mathrm{N}$ in the leaves markedly increases with increasing the NNI (Figure 9A). Considering as optimal NNI values of one, with a tolerance of $\pm 15 \%$, the fraction of $\mathrm{NO}_{3}-\mathrm{N}$ ranged from 0.1 to $20 \%$ when the NNI was lower than 0.85 ( $\mathrm{N}$ deficiency), from 14 up to $72 \%$ when the NNI was close to 1 (optimal N status) and was detected only one point at $55 \%$ of $\mathrm{NO}_{3}-\mathrm{N}$ when the NNI was higher than 1.15 ( $\mathrm{N}$ excess).

Examining the relationship between $\mathrm{NNI}$ and the leaf $\mathrm{NO}_{3}^{-}$ concentration ( $\mathrm{mg} \mathrm{kg}^{-1}$ of $\mathrm{FW}$ ) of both cultivars (Figure 9B), it was observed that the leaf $\mathrm{NO}_{3}{ }^{-}$concentration ranged from 0 to $520 \mathrm{mg} \mathrm{kg}^{-1}$ of FW when the NNI was lower than 0.85 , from 230 up to $2170 \mathrm{mg} \mathrm{kg}^{-1}$ of FW when the NNI was within the optimal interval $(0.85<\mathrm{NNI}<1.15)$, and the leaf $\mathrm{NO}_{3}{ }^{-}$concentration was about $1870 \mathrm{mg} \mathrm{kg}^{-1}$ of FW in the only point with value of NNI above 1.15 .

\section{Discussion}

\section{Agronomic and physiological response of lettuce to nitrogen input}

The variability of the crop response to $\mathrm{N}$ supply, observed in this study (Figure 2), confirms the existence of a complex interaction between plant genotype and several environmental factors (Ozores-Hampton et al., 2015; Di Gioia et al., 2017), which makes the prediction of crop $\mathrm{N}$ fertiliser requirement a difficult task.

The most common method used to define the optimal crop $\mathrm{N}$ requirements is based on the estimate of the maximum yield, or the maximum economical return (Ozores-Hampton et al., 2012), using response curves to increasing $\mathrm{N}$ rates as shown in Figure 2A and B. However, data collected from $\mathrm{N}$ rate studies can be fitted to several statistical models, and the choice of the most appropriate model in each particular cropping situation is not obvious (Cerrato and Blackmer, 1990; Bélanger et al., 2000). In this study the quadratic terms were very low and in some cases not significantly different from zero. When in doubt, the adjusted coefficient of

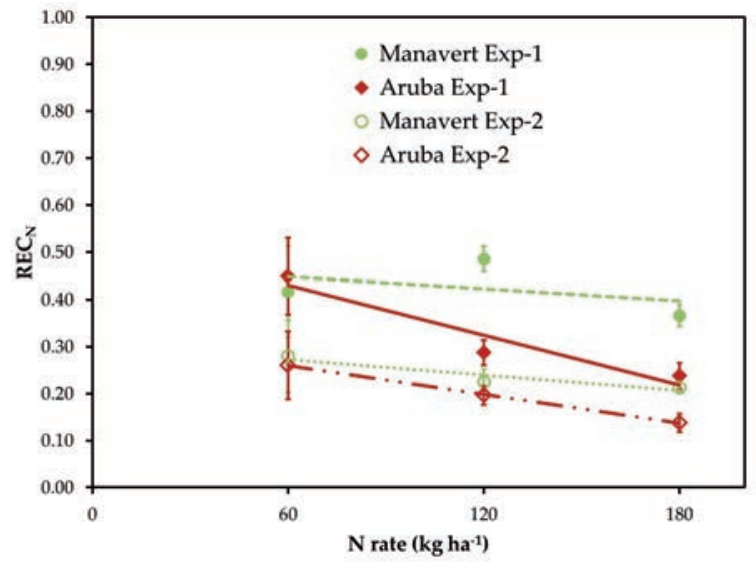

Figure 5. Effect of nitrogen fertiliser rate on apparent recovery of applied nitrogen at final harvest for cv Manavert (romaine) and cv Aruba (red oak-leaf), grown at Conversano and Polignano a Mare, during the fall-winter season of 2006-2007 (Exp-1) and 2007-2008 (Exp-2), respectively. Vertical bars represent \pm standard error $(n=3)$. 
determination $\left(\mathrm{AdjR}^{2}\right)$ was used as discriminant between different models. Nevertheless, different models with similar $\mathrm{R}^{2}$ may give different optimal fertiliser rates (Cerrato and Blackmer, 1990). Moreover, response curves are usually quite flat around the maximum point (Burns, 2006), and quadratic models tend to overestimate the response, if the maximum point on the curve is taken as optimal fertiliser rate (Cerrato and Blackmer, 1990). Although simple, as observed in this study, the major limit of this method is the variability of the estimated optimal $\mathrm{N}$ fertiliser rate between years, seasons and locations. Such variability may be explained in part by the variability of the amount of $\mathrm{N}$ available in the soil, deriving from different sources, other than the fertiliser applications. Available $\mathrm{N}$ in the soil is in fact the result of a complex balance, in which inputs ( $\mathrm{N}$ deriving from mineralisation) and outputs (leach- ing, volatilisation) of $\mathrm{N}$ in the root-zone are determined by several variable and interacting factors (soil type, soil organic matter content, soil temperature, climatic conditions, microbiological fertility). Finally, comparing the $\mathrm{N}$ response of two different lettuce types, it was observed that despite the higher fresh yield and dry biomass produced by Manavert as compared to Aruba (Figure 2A and $\mathrm{B}$ ), the optimal $\mathrm{N}$ rates estimated for the two cultivars using the yield curve-response method were similar. Moreover, in Exp-2 the estimated optimal $\mathrm{N}$ rate was higher in Aruba than in Manavert. These results further support the hypothesis that the quadratic model overestimates the optimal $\mathrm{N}$ rate (Cerrato and Blackmer, 1990). The lower response to $\mathrm{N}$ fertilisation of the aboveground DW biomass compared to the fresh biomass (Figure 2A and B) may be explained by the lower DM content observed in plants
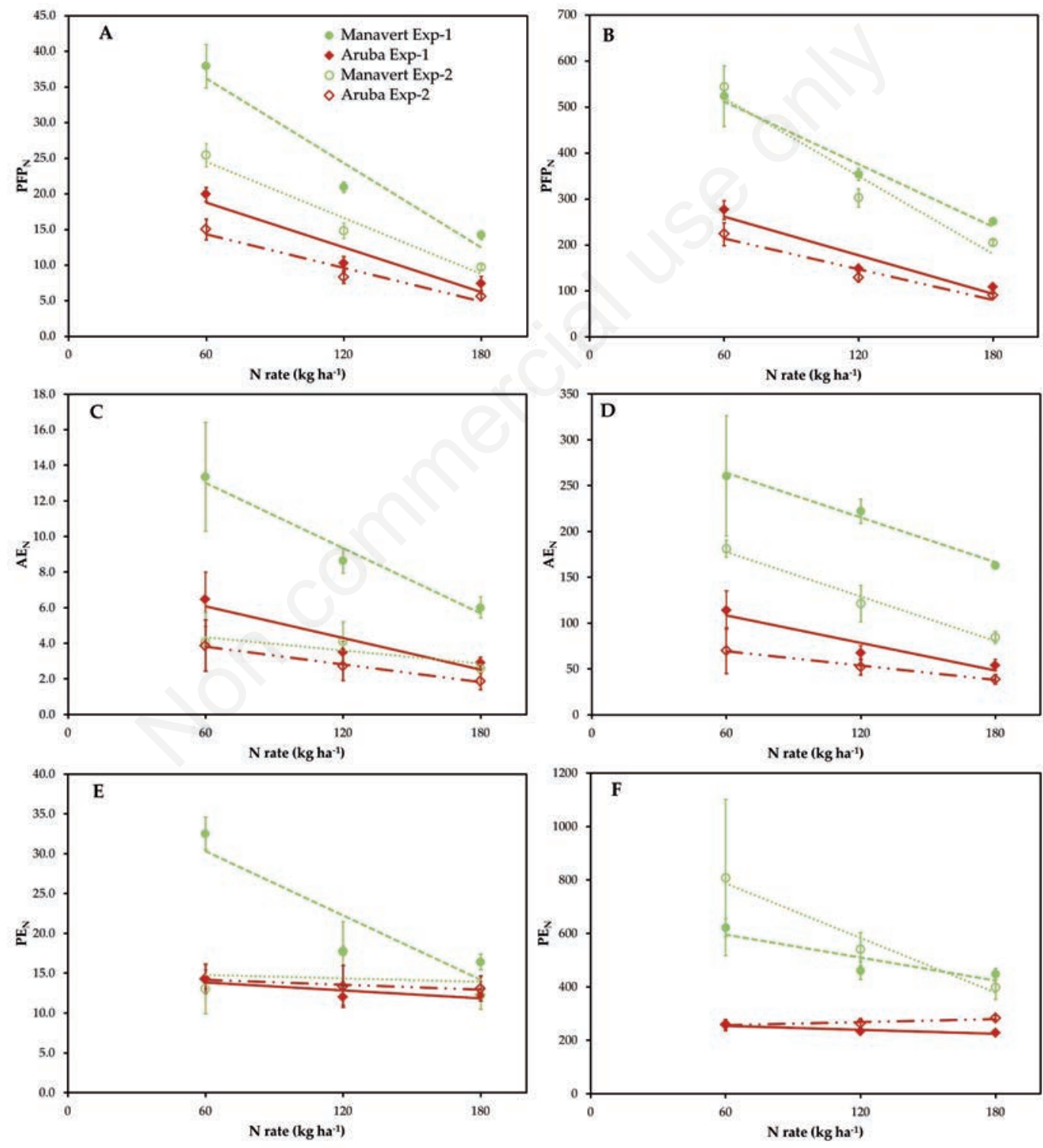

Figure 6. Effect of nitrogen fertiliser rate on partial factor productivity (A, B), agronomic efficiency (C, D), and physiological efficiency (E, F) of applied nitrogen, calculated on dry (A, C, E) and fresh (B, D, F) weight basis, at final harvest for cv Manavert (romaine) and cv Aruba (red oak-leaf), grown at Conversano and Polignano a Mare, during the fall-winter season of 2006-2007 (Exp-1) and 20072008 (Exp-2), respectively. Vertical bars represent \pm standard error $(n=3)$. 
grown at higher $\mathrm{N}$ rate (Figure $3 \mathrm{C}$ and $\mathrm{D}$ ). Likely, the lower DM content of plants grown at higher $\mathrm{N}$ rate was determined by the higher nitrate accumulation. Nitrates, exerting an osmotic effect, increase the capacity of the plant to retain water, and cause a decrease of DM content, which is consistent with the negative relationship observed between nitrates and DM content, in both cultivars and experiments (Figure 4), as well as in other studies (Reinink et al., 1987; Cárdenas-Navarro et al., 1999). At the same time, the osmotic effect of nitrate can explain the positive relationship observed between nitrate content and fresh yield (data not shown).

As hypothesised by Tei et al. (2000), the nitrate accumulation in leafy vegetables is not useful to plant growth and dry biomass accumulation, and therefore it is considered the result of $\mathrm{N}$ luxury consumption. However, the nitrate accumulation may cause an increase in water content, and thus, in fresh biomass, which may be not important in cereal and pulse crops, harvested with a low water content, but it assumes a significant role in leafy vegetables like lettuce, which are harvested fresh. The results of this study were in agreement with the findings of other authors (Tei et al., 2000; Dapoigny et al., 1996), who observed a relationship between plant $\mathrm{N}$ content and relative growth rate, only when both water contribution (fresh weight) in biomass and reduced-N (total-N minus nitrate-N) were taken into account.

These results should be duly considered in both, empirical and mechanistic crop models, currently proposed to predict crop growth, crop $\mathrm{N}$ uptake and crop water requirement (CárdenasNavarro et al., 1999). The inverse relationship between nitrate and DM content was in part considered by Seginer et al. (2004) who modified the NICOLET model, used to predict the crop N uptake, on the assumption that because of the high nitrate- $\mathrm{N}$ content of lettuce, $\mathrm{N}$ uptake depends on plants water content.

From a quality perspective, although at harvest, leaf $\mathrm{NO}_{3}{ }^{-}$content significantly increased with increasing $\mathrm{N}$ rate, the levels of $\mathrm{NO}_{3}{ }^{-}$accumulated in the edible portion were always lower than maximum limits set by the EC Regulation No. 1258/2011 for lettuce grown in open field and harvested from October $1^{\text {st }}$ to the end of March (4000 mg kg-1 of FW). The relatively low nitrate accumulation observed in both cultivars and experiments may be due to the high levels of solar radiation that characterise the Mediterranean area, even during the fall-winter season. In fact, high levels of solar radiation can substantially reduce the crop nitrate accumulation by enhancing the plant nitrate-reductase activity (Weightman et al., 2012; Di Gioia et al., 2013).

The higher leaf $\mathrm{NO}_{3}^{-}$accumulation capacity consistently observed in Aruba (non-heading) as compared to Manavert (heading lettuce), for two years, despite $\mathrm{N}$ input, highlights the importance of the genotype in determining the level of leaf $\mathrm{NO}_{3}{ }^{-}$accumulation, and the possibility to select lettuce genotypes that accumulate less nitrates (Burns et al., 2011).

\section{Nitrogen recovery and utilisation efficiency of lettuce crops}

The NUE of a crop may be considered as the product of two components: i) the $\mathrm{N}$ uptake efficiency (NupE), that expresses the ability of a genotype to acquire nitrogen from the soil; and ii) the $\mathrm{N}$ utilisation efficiency (NutE), that expresses the ability of a genotype to use $\mathrm{N}$ taken up to produce plant biomass. In this study, the $\mathrm{N}$ uptake efficiency expressed as $\mathrm{REC}_{\mathrm{N}}$ was on average $37 \%$ and $22 \%$ in Exp-1 and Exp-2, respectively (Figure 5). According to Greenwood et al. (1989), $\mathrm{REC}_{\mathrm{N}}$ should remain constant with increasing the $\mathrm{N}$ rate, until $\mathrm{N}$ supply exceeds the crop $\mathrm{N}$ demand, after which $\mathrm{REC}_{\mathrm{N}}$ should start decreasing with increasing the $\mathrm{N}$ rate. In both experiments, Manavert $\mathrm{REC}_{\mathrm{N}}$ values remained constant with increasing the $\mathrm{N}$ rate from 60 to $180 \mathrm{~kg} \mathrm{ha}^{-1}$, while Aruba $\mathrm{REC}_{\mathrm{N}}$ values decreased with increasing the $\mathrm{N}$ rate, suggesting that the two genotypes had different $\mathrm{N}$ requirements. The decline of $\mathrm{REC}_{\mathrm{N}}$ observed in Aruba $\mathrm{N}_{180}$ compared to Aruba $\mathrm{N}_{60}$ in both experiments, indicates that the higher $\mathrm{N}$ rate tested exceeded the crop $\mathrm{N}$ demand. Therefore, in the case of Aruba $\mathrm{N}$ rate should not exceed $120 \mathrm{~kg} \mathrm{ha}^{-1}$. The same $\mathrm{N}$ rates did not exceed the $\mathrm{N}$ demand of Manavert, suggesting that applications of $\mathrm{N}$ within the range 120-180 $\mathrm{kg} \mathrm{ha}^{-1}$ may be adequate for Manavert.

Values of $\mathrm{REC}_{\mathrm{N}}$ observed in these experiments were similar to those observed on lettuce in previous studies (Greenwood et al., 1989; Tei et al., 1999, 2000), however, were lower than those observed by Karam et al. (2002), confirming that lettuce crops are characterised by a low efficiency in recovering applied $\mathrm{N}$.

Manavert was more efficient than Aruba also in terms of NutE, as expressed by the indices $\mathrm{PFP}_{\mathrm{N}}, \mathrm{AE}_{\mathrm{N}}$ and $\mathrm{PE}_{\mathrm{N}}$, calculated both on dry (Figure 6A, C, E) and fresh weight basis (Figure 6B, D, F).

Proposed primarily to evaluate the efficiency of grain and pulse crops characterised by low water content, NutE indices are usually calculated on DW basis, also to enable the comparison between different species and environments. Nevertheless, the
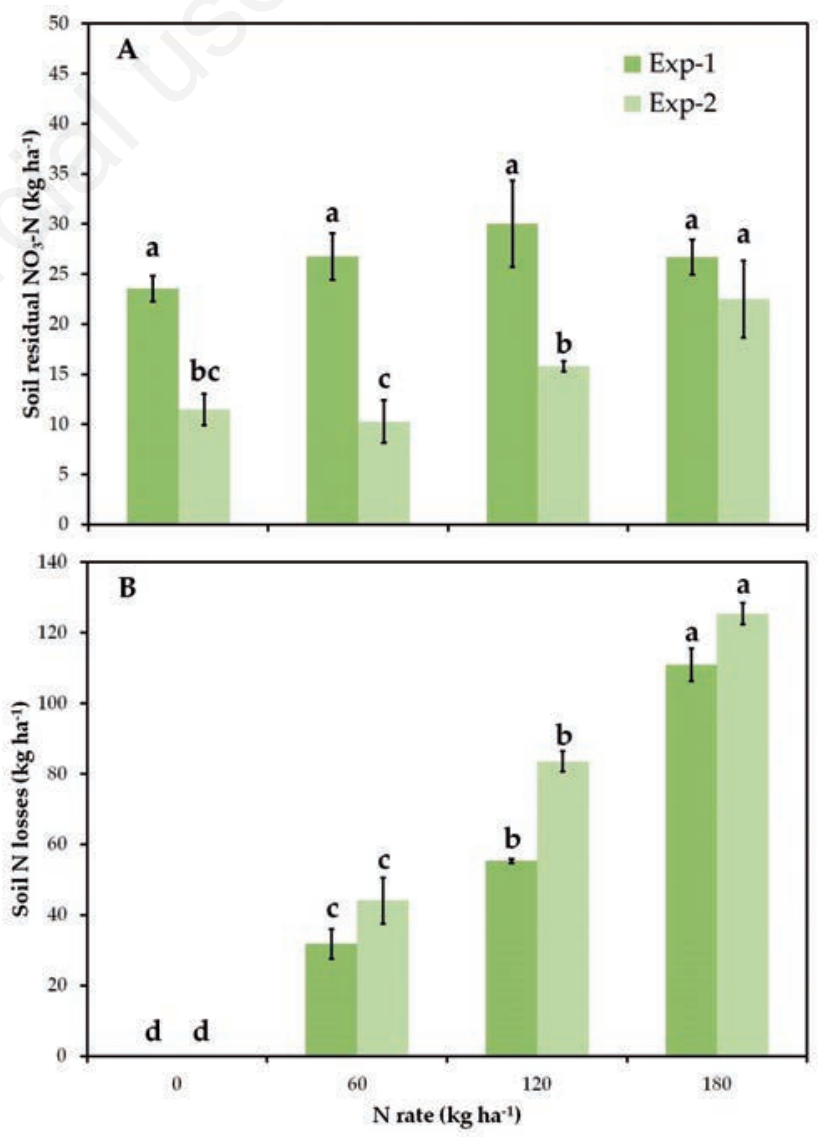

Figure 7. Effect of nitrogen rate on residual soil nitrate-nitrogen (A) (in the top $30 \mathrm{~cm}$ ) and apparent soil nitrogen losses (B) determined at harvest in plots of the cv Manavert (romaine), grown at Conversano and Polignano a Mare during the fall-winter season of 2006-2007 (Exp-1) and 2007-2008 (Exp-2), respectively. Vertical bars represent \pm standard error $(n=3)$. Different letters within each experiment indicate significant differences at $\mathbf{P}=0.05$. 
results of this study suggest that for lettuce crops, characterised by relatively high water content, considering that the $\mathrm{N}$ rate may affect the water content, it may be meaningful to express the NutE indices also on FW basis.

As expected, $\mathrm{PFP}_{\mathrm{N}}$, which represents the yield per unit of $\mathrm{N}$ fertiliser applied, significantly decreased with increasing $\mathrm{N}$ fertiliser rate, and was higher in Manavert than in Aruba. Observed $\mathrm{PFP}_{\mathrm{N}}$ values were comparable to those reported by Conversa et al. (2004) on hydroponically-grown butterhead lettuce. The scarce influence of $\mathrm{N}$ rate on $\mathrm{AE}_{\mathrm{N}}$ in both cultivars and experiments, was mainly due to the high variability observed between replications at $\mathrm{N}_{60}$ (Figure 6C), which may be explained by the fact that at lower $\mathrm{N}$ rates, crop yield performances are more susceptible to variations depending on the amount of $\mathrm{N}$ available in the soil, deriving from alternative sources, other than the fertiliser. The $\mathrm{PE}_{\mathrm{N}}$ which represents the ability of a plant to transform $\mathrm{N}$ acquired from fertiliser into yield, and depends mostly on the genotype characteristics and only in part on environmental factors (Dobermann, 2005), was not influenced by $\mathrm{N}$ supply, either when expressed in terms of DW and FW basis, except in the case of Manavert $N_{60}$ in Exp-1. The higher $\mathrm{PE}_{\mathrm{N}}$ value observed in Exp-1 in plants of Manavert grown at lower $\mathrm{N}$ rate $\left(\mathrm{N}_{60}\right)$ in comparison to those grown at higher $\mathrm{N}$ rates, was due to environmental factors rather than to genotype traits, as demonstrated by the variability observed between replications for both DW and $\mathrm{N}_{\text {acc }}$ in treatment $\mathrm{N}_{60}$.

Values of NutE estimated in this study were lower than those observed from other authors in cereal crops (Cassman et al., 2002; Dobermann, 2005), while were comparable to those observed by Lòpez-Bellido et al. (2005) on rainfed wheat under Mediterranean environment.

\section{Soil nitrogen losses estimate}

At the end of the crop cycle, although some residual $\mathrm{NO}_{3}-\mathrm{N}$ was found in the top $30-\mathrm{cm}$ of soil in both experiments, estimated $\mathrm{N}$ loss from the same soil layer were high, and in treatment $\mathrm{N}_{180}$ reached 111 and $125 \mathrm{~kg} \mathrm{ha}^{-1}$ of $\mathrm{N}$ in Exp-1 and Exp-2, respectively, further proving the low $\mathrm{N}$ recovery efficiency of lettuce crops (Figure 7). Moreover, in absence of a catch crop, also soil residual $\mathrm{NO}_{3}-\mathrm{N}$ may be subject to environmental losses.

The variability of climatic conditions, soil texture, biological and chemical properties makes it difficult any kind of comparison with other situations; however, these results may be considered normal for lettuce crops, and suggest that under the specific conditions, the mineralisation of the soil organic matter may provide substantial amounts of $\mathrm{N}$ for the crop. Therefore, to improve crop NUE and minimise the risks of $\mathrm{N}$ losses, the amount of $\mathrm{N}$ potentially deriving from mineralisation process should be accounted in the fertilisation programme.
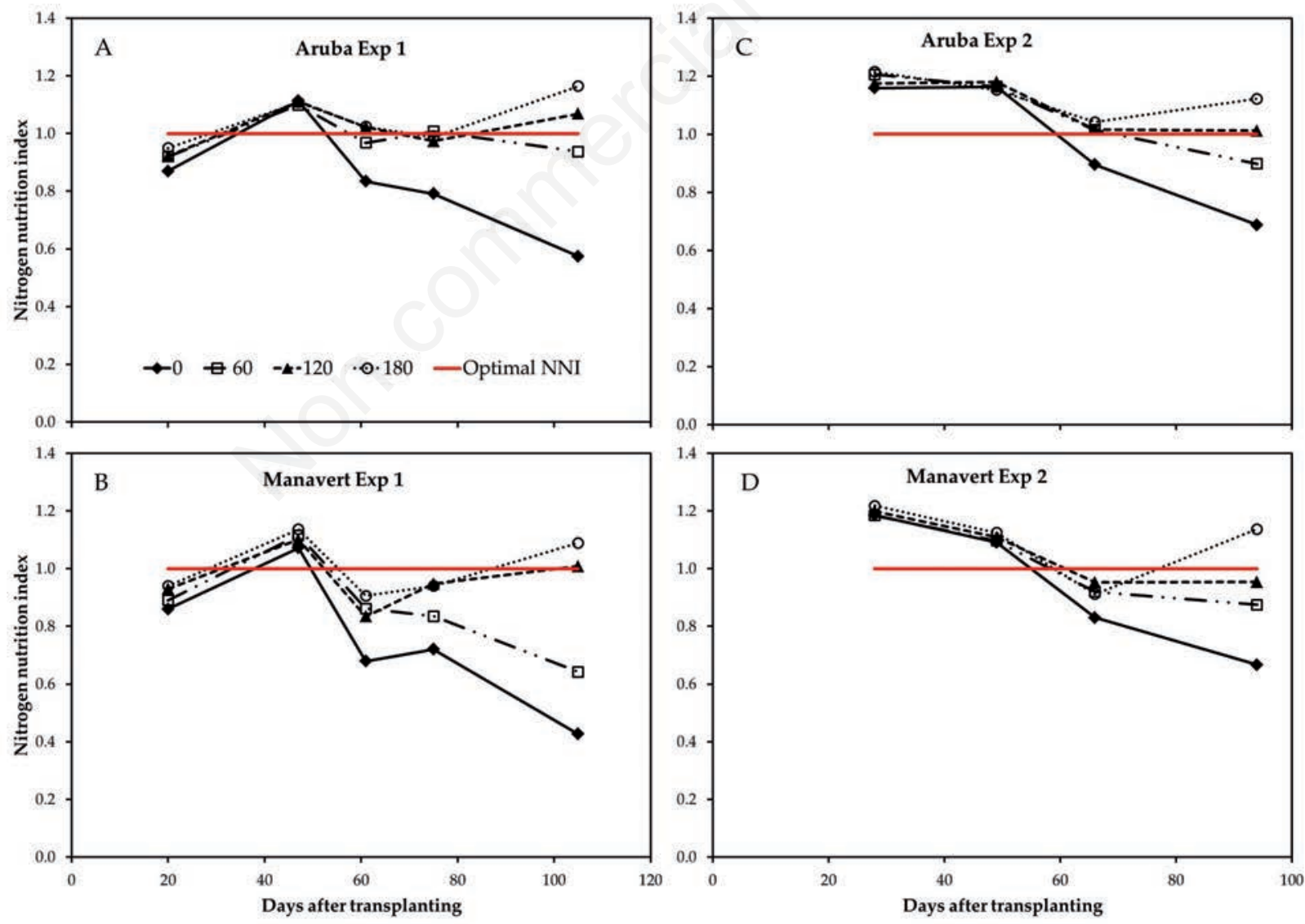

Figure 8. Effect of nitrogen rate on the nitrogen nutrition index time course in cv Aruba $(A, C)$ and cv Manavert (B, D) grown at Conversano and Polignano a Mare during the fall-winter season of 2006-2007 (Exp-1) and 2007-2008 (Exp-2), respectively. Nitrogen nutrition index was calculated according to Lemaire et al. (1989) using the critical nitrogen dilution curve proposed by Tei et al. (2003) for lettuce. Standard error bars were smaller than the symbols used in the graphs $(n=3)$. 


\section{Nitrogen nutrition index and nitrate content as indica- tors of the crop nitrogen status}

The NNI represents an indicator of the crop N status and may be used as a guide to optimise the $\mathrm{N}$ fertilisation programme in terms of timing and $\mathrm{N}$ application rate, enabling the adjustment of $\mathrm{N}$ fertiliser applications to $\mathrm{N}$ demand and corresponding target yield, in any moment of the crop growth cycle (Lemaire et al., 2008).

Analysing a posteriori the NNI time course of a crop is possible to define when $\mathrm{N}$-deficiency and/or N-excess occurred, and thus, when and how much $\mathrm{N}$ fertiliser should be applied to the crop. In this study, the NNI analysis revealed that in both cultivars and experiments, only the application of $120 \mathrm{~kg} \mathrm{ha}^{-1}$ of $\mathrm{N}$ ensured the maintenance of an optimal crop $\mathrm{N}$ status during the entire crop cycle, while $\mathrm{N}$ deficiency or excess were observed at lower and at higher $\mathrm{N}$ rates, respectively. These results further confirm that yield $\mathrm{N}$ response quadratic models overestimate the optimal $\mathrm{N}$ rates. Examining the NNI pattern, it was observed that at lower N rates, $\mathrm{N}$ deficiency occurred only after 60 DAT in correspondence of the maximum crop growth rate (Figure 9); while, $\mathrm{N}$ excess occurred at the highest $\mathrm{N}$ rate, either at the beginning of the crop cycle in Exp-2, or at the end of the crop cycle. These results highlight the importance of splitting $\mathrm{N}$ fertiliser applications to avoid both $\mathrm{N}$ excess and deficiency.
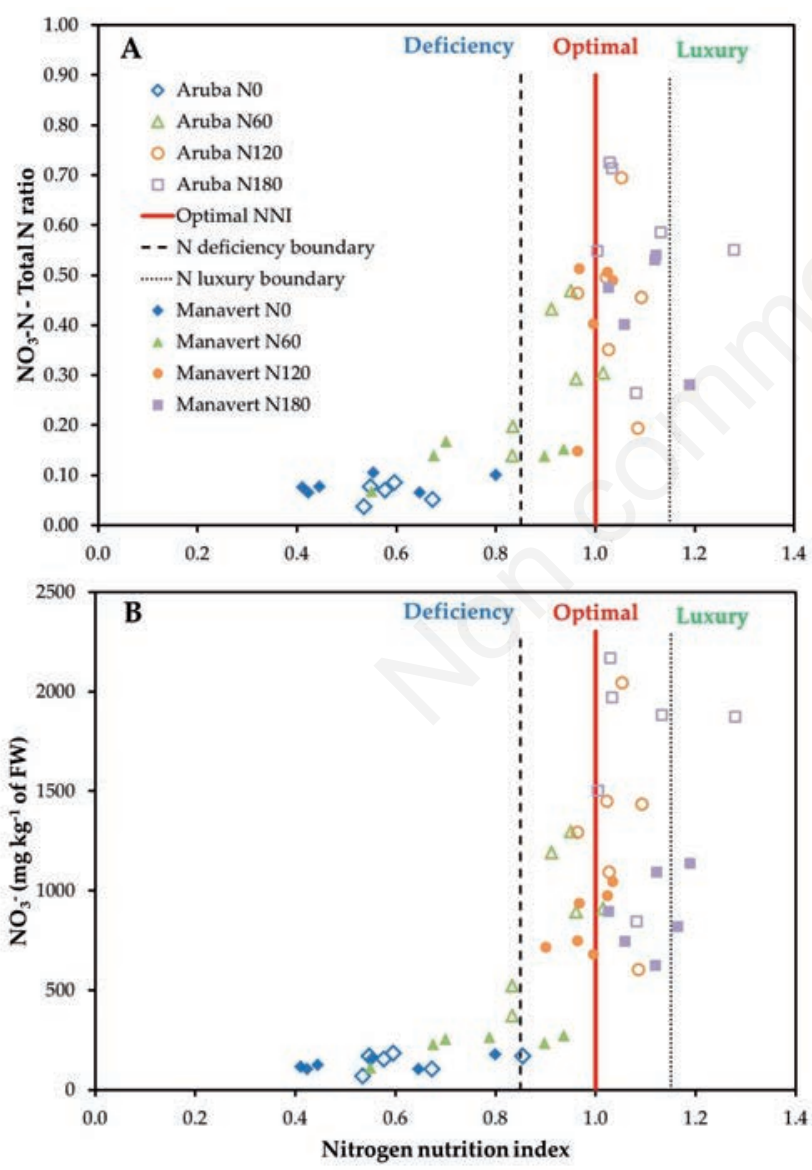

Figure 9. Relationship between nitrogen nutrition index and plant nitrate-nitrogen to total-nitrogen ratio (A) and between nitrogen nutrition index and nitrate concentration $(B)$ in cv Aruba and Manavert, grown with different nitrogen rates, at Conversano and Polignano a Mare during the fall-winter season of 2006-2007 (Exp-1) and 2007-2008 (Exp-2), respectively.
Although the NNI is an established and reliable indicator of the crop $\mathrm{N}$ status, its determination is time consuming and requires laboratory equipment and expertise that farmers usually do not have. For this reason, it is necessary to develop methods to indirectly estimate the NNI (Lemaire et al., 2008). Pooling the data of the two experiments and lettuce genotypes, an empirical relationship was found between leaf $\mathrm{NO}_{3}-\mathrm{N}$ to total-N ratio and $\mathrm{NNI}$ (Figure 9A), and an equivalent relationship was observed between $\mathrm{NNI}$ and leaf $\mathrm{NO}_{3}{ }^{-}$concentration expressed on $\mathrm{FW}$ basis $\left(\mathrm{mg} \mathrm{kg}^{-1}\right.$ of FW; Figure 9B). Although the equivalence of the two relationships may appear obvious, it is of fundamental importance for the practical application of NNI as a diagnostic tool of the crop N status. In fact, while it is difficult to analyse the fraction of $\mathrm{NO}_{3}-\mathrm{N}$ on the total-N, the leaf $\mathrm{NO}_{3}{ }^{-}$concentration, may be easily determined on-farm, directly by growers, using ion selective electrodes or other rapid methods (Di Gioia et al., 2010; Peña-Fleitas et al., 2015).

Despite the great variability of the $\mathrm{NO}_{3}-\mathrm{N}$ to total- $\mathrm{N}$ ratio and leaf $\mathrm{NO}_{3}{ }^{-}$concentration for a given $\mathrm{N}$ level, as observed also by Justes et al. (1994), examining the variation of the leaf $\mathrm{NO}_{3}{ }^{-}$concentration in relation to the NNI, it was possible to associate $\mathrm{N}$ deficiency or $\mathrm{N}$ excess crop status to specific leaf $\mathrm{NO}_{3}{ }^{-}$concentration levels for both cultivars. In both cultivars and experiments, leaf $\mathrm{NO}_{3}{ }^{-}$values below $500 \mathrm{mg} \mathrm{kg}^{-1}$ of $\mathrm{FW}$ were consistently associated to $\mathrm{N}$ deficiency, suggesting that to assure an optimal $\mathrm{N}$ status the leaf $\mathrm{NO}_{3}^{-}$content should be above this threshold. Moreover, considering as optimal the status of plants grown at the rate of $120 \mathrm{~kg} \mathrm{ha}^{-1}$ of $\mathrm{N}$, to assure an optimal $\mathrm{N}$ status with a tolerance of $\pm 15 \%$, the leaf $\mathrm{NO}_{3}{ }^{-}$concentration should range between 600 and $1000 \mathrm{mg} \mathrm{kg}^{-1}$ of FW in Manavert, and between 600 and $1500 \mathrm{mg} \mathrm{kg}^{-1}$ of FW in Aruba, which showed a tendency to accumulate more $\mathrm{NO}_{3}^{-}$.

These results suggest that, although empirical, the relationship between leaf $\mathrm{NO}_{3}{ }^{-}$content and NNI may be used to define the leaf $\mathrm{NO}_{3}{ }^{-}$range associated to an optimal $\mathrm{N}$ status, or threshold limits to avoid $\mathrm{N}$ deficiency and/or luxury consumption for specific crops and growth stages. Developing these specific leaf $\mathrm{NO}_{3}{ }^{-}$concentration thresholds for different crops and using rapid and low cost methods such as $\mathrm{NO}_{3}{ }^{-}$ion-selective electrodes, growers may be able to monitor directly the nutritional status of their crops and dynamically adjust the $\mathrm{N}$ fertilisation programme according to the actual crop demand.

\section{Conclusions}

Fresh and dry biomass of romaine (cv Manavert) and red oakleaf (cv Aruba) lettuce varied in response to $\mathrm{N}$ inputs according to a quadratic model in both fall-winter seasons. Nevertheless, the response varied from year to year and was different for the two lettuce genotypes. Manavert had higher $\mathrm{N}$ recovery and utilisation efficiency as compared to Aruba, suggesting that heading lettuce genotypes are more efficient than non-heading lettuce types. Therefore, NUE may be substantially improved by selecting more efficient lettuce genotypes.

Plants grown at higher $\mathrm{N}$ rates accumulated more $\mathrm{NO}_{3}{ }^{-}$in the leaves and a negative relationship was observed between leaf $\mathrm{NO}_{3}{ }^{-}$ and DM content. Such interesting relationship characterise lettuce from other crops harvested at relatively higher DM content, and should be properly considered in the $\mathrm{N}$ fertilisation management.

The analysis of the NNI time course of the two genotypes revealed that only the application of $120 \mathrm{~kg} \mathrm{ha}^{-1}$ of $\mathrm{N}$ assured an 
optimal crop $\mathrm{N}$ status, while $\mathrm{N}$ deficiency and excess were observed at lower and higher $\mathrm{N}$ rates, respectively. An empirical relationship was found between leaf $\mathrm{NO}_{3}{ }^{-}$concentration and $\mathrm{NNI}$, which may be used to define optimal leaf $\mathrm{NO}_{3}{ }^{-}$ranges for specific lettuce crops and growth stages. Using the $\mathrm{NNI}-\mathrm{NO}_{3}{ }^{-}$relationship growers may be able to predict and indirectly monitor the NNI, and the crop $\mathrm{N}$ status, on site-specific basis, by measuring the leaf $\mathrm{NO}_{3}^{-}$ concentration with simple rapid on-farm tests.

Combining the selection of more efficient lettuce genotypes with the dynamic and site-specific adjustment of the $\mathrm{N}$ fertilisation programme based on the actual crop $\mathrm{N}$ status may contribute to improve the crop NUE, minimise the risks of $\mathrm{N}$ losses and the crop environmental impact, while maintaining high yields and quality standards.

\section{References}

Bélanger G, Walsh JR, Richards JE, Milburn PH, Ziadi N, 2000. Comparison of three statistical models describing potato yield response to nitrogen fertilizer. Agron. J. 92:902-8.

Boari F, Cefola M, Di Gioia F, Pace B, Serio F, Cantore V, 2013. Effect of cooking methods on antioxidant activity and nitrate content of selected wild Mediterranean plants. Int. J. Food Sci. Nutr. 64:870-6.

Broadley MR, Escobar-Gutierrez AJ, Burns A, Burns IG, 2000. What are the effects of nitrogen deficiency on growth components of lettuce? New Phytol. 147:519-26.

Burns IG, 2006. Assessing $\mathrm{N}$ fertiliser requirements and the reliability of different recommendation systems. Acta Hort. 700:3548.

Burns IG, Zhang K, Turner MK, Lynn J, McClement S, Hand P, Pink D, 2011. Genotype and environment effects on nitrate accumulation in a diversity set of lettuce accessions at commercial maturity: the influence of nitrate uptake and assimilation, osmotic interactions and shoot weight and development. J. Sci. Food Agr. 91:2217-33.

Cárdenas-Navarro R, Adamowicz S, Robin P, 1999. Nitrate accumulation in plants: a role for water. J. Exp. Botany 50:613-24.

Cassman KG, Dobermann A, Walters DT, 2002. Agroecosystems, nitrogen-use efficiency and nitrogen management. Ambio 31:132-40.

Cerrato ME, Blackmer AM, 1990. Comparison of models for describing corn yield response to nitrogen fertilizer. Agron. J. 82:138-43.

Conversa G, Bonasia A, Di Gioia F, Elia A, 2015. A decision support system $(\mathrm{Ges} \mathrm{CoN})$ for managing fertigation in vegetable crops. Part II. Model calibration and validation under different environmental growing conditions on field grown tomato. Front. Plant Sci. 6:495.

Conversa G, Gonnella M, Santamaria P, 2004. Growth, yield, and mineral content of butterhead lettuce (Lactuca sativa var. capitata) grown in NFT. Acta Hort. 659:621-8.

Cui Z, Zhang F, Chen X, Dou Z, Li J, 2010. In-season nitrogen management strategy for winter wheat: maximizing yields, minimizing environmental impact in an over-fertilization context. Field Crop Res. 116:140-6.

Dapoigny L, Robin P, Raynal-Lacroix C, Fleury A, 1996. Relation entre le vitesse relative de croissance et la teneur en azote chez la laitue (Lactuca sativa L.). Effets de l'ombrage et du niveau de l'alimentation minérale. Agronomie 16:529-39.

Di Gioia F, Gonnella M, Buono V, Ayala O, Cacchiarelli J,
Santamaria P, 2017. Calcium cyanamide effects on nitrogen use efficiency, yield, nitrates and dry matter content of lettuce. Agron. J. 109:354-62.

Di Gioia F, Gonnella M, Santamaria P, 2013. Contribution of leafy vegetables to dietary nitrate intake and regulations. In: S. Umar, N.A. Anjum, N.A. Khan (eds.) Nitrate in leafy vegetables: toxicity and safety measures. I.K. International Publishing House Pvt. Ltd., New Delhi, India, pp 2-16.

Di Gioia F, Simonne EH, Gonnella M, Santamaria P, Gazula A, Sheppard Z, 2010. Assessment of ionic interferences to nitrate and potassium analyses with ion-selective electrodes. Commun. Soil Sci. Plan. 41:1750-68.

Dobermann A, 2005. Nitrogen use efficiency: state of the art. pp 116 in Proc. IFA Int. Workshop on Enhanced-Efficiency Fertilizers, Frankfurt, Germany, 28-30 June 2005. Available from: http://digitalcommons.unl.edu/agronomyfacpub/316

Elia A, Conversa G, 2012. Agronomic and physiological responses of a tomato crop to nitrogen input. Eur. J. Agron. 40:64-74.

European Commission, 1997. Commission Regulation of 31 January 1997 setting maximum levels for certain contaminants in foodstuffs, 194/97/EC. In: Official Journal, L 31, pp. 48-50.

European Commission, 2010. Report from the Commission to the Council and the European Parliament on implementation of Council Directive 91/676/EEC concerning the protection of waters against pollution caused by nitrates from agricultural sources based on Member State reports for the period 2004 2007. Document 52013DC0683. European Commission, Brussels, Belgium.

European Commission, 2011. Regulation of 2 December 2011 amending Regulation (EC) No. 1881/2006 as regards maximum levels for nitrates in foodstuffs, 1258/2011/EC. In: Official Journal, L 320, pp. 15-17.

FAOSTAT, 2016. Food and Agriculture Organization of the United Nations, Statistic Division. Available from: http://faostat3. fao.org/

Hirel B, Le Gouis J, Ney B, Gallais A, 2007. The challenge of improving nitrogen use efficiency in crop plants: towards a more central role for genetic variability and quantitative genetics within integrated approaches. J. Exp. Bot. 58:2369-87.

Hord NG, Tang Y, Bryan NS, 2009. Food sources of nitrates and nitrites: the physiologic context for potential health benefits. Am. J. Clin. Nutr. 90:1-10.

Good AG, Shrawat AK, Muench DG, 2004. Can less yield more? Is reducing nutrient input into the environment compatible with maintaining crop production? Trends Plant Sci. 9:597605.

Greenwood DJ, Kubo KI, Burns IG, Draycott A, 1989. Apparent recovery of fertilizer $\mathrm{N}$ by vegetable crops. Soil Sci. Plant Nutr. 35:367-81.

Justes E, Mary B, Meynard JM, Machet JM, Thelier-Huché L, 1994. Determination of a critical nitrogen dilution curve for winter wheat crops. Ann. Bot. 74:397-407.

Karam F, Mounzer O, Sarkis F, Lahoud R, 2002. Yield and nitrogen recovery of lettuce under different irrigation regimes. J. Appl. Hort. 4:70-6.

Lemaire G, Gastal F, Salette J, 1989. Analysis of the effect of N nutrition on dry matter yield of a sward by reference to potential yield and optimum N content. pp 179-180 in Proc. XVI Int. Grassland Congress, Nice, France.

Lemaire G, Jeuffroy M-H, Gastal F, 2008. Diagnosis tool for plant and crop $\mathrm{N}$ status in vegetative stage. Theory and practices for crop N management. Eur. J. Agron. 28:614-24.

Lòpez-Bellido L, Lòpez-Bellido RJ, Redondo R, 2005. Nitrogen 
efficiency in wheat under rainfed Mediterranean conditions as affected by split nitrogen application. Field Crop Res. 94:8697.

Ozores-Hampton M, Di Gioia F, Sato S, Simonne E, Morgan K, 2015. Effects of nitrogen rates on nitrogen, phosphorous, and potassium partitioning, accumulation, and use efficiency in seepage-irrigated fresh market tomatoes. HortScience 50:1636-43.

Ozores-Hampton M, Simonne E, Roka F, Morgan K, Sargent S, Snodgrass C, McAvoy E, 2012. Nitrogen rates effects on the yield, nutritional status, fruit quality, and profitability of tomato grown in the spring with subsurface irrigation. HortScience 47:1129-33.

Peña-Fleitas MT, Gallardo M, Thompson RB, Farneselli M, Padilla FM, 2015. Assessing crop N status of fertigated vegetable crops using plant and soil monitoring techniques. Ann. Appl. Biol. 167:387-405.

Reinink K, Groenwold R, Bootsma A, 1987. Genotypical differences in nitrate content in Lactuca sativa L. and related species and correlation with dry matter content. Euphytica 63:11-8.

Salomez J, Hofman G, 2009. Nitrogen nutrition effects on nitrate accumulation of soil-grown greenhouse butterhead lettuce. Comm. Soil Sci. Plan. 40:620-32.

Santamaria P, 2006. Nitrate in vegetables: toxicity, content, intake and EC regulation. J. Sci. Food Agr. 86:10-7.

Seginer I, Bleyaert P, Breugelmans M, 2004. Modelling ontogenetic changes of nitrogen and water content in lettuce. Ann. Bot. 94:393-404.

Simonne AH, Simonne EH, Eitenmiller RR, Mills HA, Cresman CP, 1997. Could the Dumas method replace the Kjeldahl diges- tion for nitrogen and crude protein determinations in foods? J. Sci. Food Agr. 73:39-45.

Simonne E, Hutchinson C, De Valerio J, Hochmuth R, Treadwell D, Wright A, Bielinski S, Whidden A, McAvoy E, Zhao X, Olczyk T, Gazula A, Ozores-Hampton M, 2010. Current knowledge, gaps, and future needs for keeping water and nutrients in the root zone of vegetables grown in Florida. HortTechnology 20:143-52.

Tei F, Benincasa P, Guiducci M, 1999. Nitrogen fertilization of lettuce, processing tomato and sweet pepper: yield, nitrogen uptake and the risk of nitrate leaching. Acta Hort. 506:61-7.

Tei F, Benincasa P, Guiducci M, 2000. Effect of nitrogen availability on growth and nitrogen uptake in lettuce. Acta Hort. 533:385-92.

Tei F, Benincasa P, Guiducci M, 2003. Critical nitrogen concentration in lettuce. Acta Hort. 627:187-94.

USDA, 2003. Soil taxonomy: keys to soil taxonomy. United States Department of Agriculture, Natural Resources Conservation Service, Washington, DC, USA.

US Environmental Protection Agency, 2010. Clean water act. Available from: http://www.epa.gov/agriculture/lcwa.html

Weightman RM, Huckle AJ, Roques SE, Ginsburg D, Dyer CJ, 2012. Factors influencing tissue nitrate concentration in fieldgrown wild rocket (Diplotaxis tenuifolia) in southern England. Food Add. Contam. 29:1425-35.

WRB, 2006. World reference base for soil resources: a framework for international classification, correlation and communication. International Union of Soil Sciences, World Soil Information and Food and Agriculture Organization of the United Nations, Rome, Italy. 